UDC 344:638.26

https://doi.org/10.33619/2414-2948/41/41

JEL classification: J01; J45; Q18

AGRIS E80

\title{
THE SCIENTIFIC BASIS OF THE RELATIONSHIPS BETWEEN SILK SEED PRODUCTION COMPANIES IN UZBEKISTAN
}

\author{
CAskarov N., Ph.D., Scientific Research Institute Economics \\ of Agriculture, Tashkent, Uzbekistan
}

CSadullayev U., Scientific Research Institute Economics

of Agriculture, Tashkent, Uzbekistan,u.n.sadullaev@mail.ru

\section{НАУЧНАЯ ОСНОВА ОТНОШЕНИЙ МЕЖДУ ОРГАНИЗАЦИЯМИ ГРЕНОПРОИЗВОДСТВА В УЗБЕКИСТАНЕ}

(САскаров Н. Н., канд. экон. наук, Научно-исследовательский институт экономики сельского хозяйства, г. Ташкент, Узбекистан

(ССадуллаев У. Н., Научно-исследовательский институт экономики сельского хозяйства, 2. Ташкент, Узбекистан, u.n.sadullaev@mail.ru

Abstract. This article explores the scientific basis of relationships between enterprises of the silk seed production system. Factors influencing the formation of relations between enterprises are grouped, including economic, organizational-demographic, and also natural-geographical factors.

Аннотащия. В данной статье изучены научные основы взаимоотношений между предприятиями системы гренажа. Сгруппированы факторы, влияющие на формирование отношений между предприятиями, в том числе сгруппированы экономические, организационно-демографические, а также природно-географические факторы.

Keywords: silk seed production, relationships, factors, economic relationship, socio-economic relations, organizational and economic relations.

Ключевые слова: гренопроизводство, отношения, факторы, экономические отношения, социально-экономические отношения, организационные и экономические отношения.

Decision-making on market relations in our country has led to a new impetus for the interaction in the economic sectors. Despite the fact that in the early years of independence, various forms of farming have been tested, the focus has been on formulating a demand based economy, based on the essence of market law, by gradually introducing different forms of ownership in the whole economy.

In a market economy, any activity will focus on achieving the desired effect. The resulting effect will encourage the practitioner to act irrespective of its material or non-material form and force him to seek the best possible ways to achieve it in a competitive environment. This is the basis of society's development. In other words, members of society continue to look for ways and methods of mutual relations that are in the best interest of the parties. In the economy of the economy, the results of any activity are focused on achieving the desired outcomes. The resulting effect will encourage the practitioner to act irrespective of its material or non-material form and force him to seek the best possible ways to achieve it in a competitive environment. This is the basis 
of society's development. That is, members of the community will continue to look for ways and methods that are in line with the interests of the parties.

This economic relationship is the most effective and positive impetus to the interaction of various market entities in their pursuit of productivity. Economic relations will always be in the focus of bilateral relations, allowing market entities to evaluate the outcomes of their work, as well as their ability to build a solid foundation for their future activities, as well as favorable relationships between them.

When dealing with economic relations, it is important to pay attention to the essence of the essence and the way they are expressed. In scientific literature, we can observe the following comments and theoretical views on economic relations.

Economic relations are a set of developing relationships between people in production, distribution and consumption of goods.

Economic relations are material intermediary relations that develop in the process of production and consumption of goods and services [1].

The main purpose of the participants in mutual relations is to benefit that which is recognized as the general law of nature and society. Adam Smith, the founder of classical economics, wrote in his book The Treasures of the Nations and Its Causes (1776): "The relationship and mutual benefit are the results of mathematics. The reason is that this is the only way to make a profit" [2].

American researchers R. Stroop and D. Gartt, in his work The Algebraic alphabet, say that "Mutual relations of economic subjects can influence the form and effect of the economy. A negative impact on the positive effects of economic interests (demand, competition, and private ownership) in a free society (equal distribution of income, social equality and growth)" [4].

Based on the above facts, we can say that the basis of the relationship in the society is the economic relationship. In other words, economic relations have their own influence in any form of interaction between market entities.

The outcome of any community relationship should be reflected in the improvement of the living standards of the members of society. Therefore, discussions on the interrelation, role and necessity of economic relations in the relationships of different subjects have always been in the focus of attention of economist scientists and enrich the content of the disputes.

Particular attention is paid to the development of different forms of interaction between market entities in the following forms:

-socio-economic relations or production relations;

-technical-economic relations;

-organizational-economic relationships.

Socio-economic relations are the relationships between social classes, social groups, individual groups, and community members. Socioeconomic relations mainly develop according to the type of ownership of production conditions and results.

Organizational-economic relations are the forms of relationships that arise from the inability to produce, distribute, exchange and consume goods and services without certain organizations, structures, or networks.

Organizational and economic relations include relations in credit, finance, marketing, money circulation, insurance, commodity and stock exchanges, and so on. They include the forms and methods of management, the market system, entrepreneurship and commodity relationships.

Technical and economic relations are primarily related to the production and economic activities of the financial sector, car hanes, accessory units and structures, their impact on technology development and operation, production technology and production support. 
Technical and economic relations are a system of relationships involving the production processes, including the use of raw materials, fuel, energy, transport and technical structures.

In general, with the study of the scientific and theoretical bases of relationships between market entities, we can say that the relationships between entities that are not interconnected from chains of production, from production to production to commodities and services, cover the aforementioned aspects and, while serving the interests of the parties involved, and contribute to the development of society.

This is especially true for the economy of our country, where the rules of the market economy are widely spread and reflected in practice, and in recent years the liberalization of the economy has become more relevant.

In particular, we can observe the wide application of modern methods and methods of interaction between the branches of the economy of the country, which has a long history of production history, experiments and traditions, growing in demand for grown products.

If we look at the stages of the development of all sectors, we can see that the relationship between the subjects of the productive economy has grown into the economic system.

The saddle, which is called the 'heart' of the silkworm breed, is a system of seeds of seed that can produce seeds for this network and, if necessary, can influence the development direction and tendencies.

The silkworm seed and cocoon production are one of the ancient historical roots of leading on agricultural sectors of Uzbekistan. The advantages of this sphere are that producers have been applied traditional techniques and the agricultural methods had been deeply acquired as well, our producers are the rich experiences and the appropriate climatic environment can have got us several time productions during in the year. The development of the silkworm seed sector has influenced the growth of export potential and can be increased the currency money, including to can be influenced by the flow of the local and foreign investments. Also, these sector enterprises are created many new workplaces; as well the majority women can be worked in the silkworm seed factories, so this way is great importance in rising of employment which is one of the highest importances of solving employment problem in our republic [3].

Considering the importance, as well as to ensure the integrated development of the silk industry on the basis of creating a single full organizational and technological chain aimed at intensive development of the feed base, continuous improvement of the processes of feeding and harvesting silkworm cocoons, widespread introduction of efficient production methods and in-depth processing of silkworm cocoons, raw silk, silk yarn, establishing the production of finished silk products, increasing the export potential of the industry, and the increase in employment and income, by the republic's government adopted a package of measures for the development of sericulture [3].

As noted above, the silkworm seedlings are made up of silkworm breeding units, silkworms, silkworm breeders, and their relationships are based on market principles. In other words, the organizational basis of production in the industry can be traced to market law based on supply and demand.

However, practice does not always compensate for the correct and precise operation of the organizational mechanisms. In other words, the ability to obtain the desired effect as a result of various external and internal factors affecting it is limited [4].

Therefore, it is important to explore the institutional bases for scientific and practical research of the relationships between silkworm breeding systems today and to support them in the interests of the parties through the economic dimension. 
Studies show that relationships between silkworm breeding systems are available in the following forms. Specifically:

-Technical and economic relations, that is:

- relationships with storage, transportation, delivery and quality control of seeds;

- relationships with technology and technology supply and supply.

-Organizational and economic relations, that is:

- relationships with contractual and contract payments, forward and full payments

- relationships with insurance, lending, leasing and other financial services

- customs payments, taxes, subsidies and grants, donor funding.

-Socio-economic relationships:

- specialist training, refresher training, explanation, relationships with scientific supply;

- relationships with patents, protection of copyrighted, and copyrighted royalties.

However, as emphasized, in practice all relationships are not properly and effectively influenced by the human factor. As a result, the breakdown in one of the chains of relationships has a direct impact on other links, negatively affecting the efficiency of the system.

A number of factors influence the relationships between silkworm breeding organizations and the relationships that they serve with a positive or negative character.

By studying these factors, it enables us to eliminate the causes of origin, rather than combating the well-known forms of negative attitudes that have arisen in the relationships between clay seedlings.

During research in carpenters that produce piled seeds in different parts of the country, we consider it appropriate to study the factors that affect the relationship between grouping them into groups. Particularly high concentrations of factors were selected in their grouping (Figure). These are the following factors:

Economic factors - the amount of taxes and mandatory payments, the form and terms of payment, interest rates and terms of the loan, etc. In other words, the amount of taxes and mandatory payments, as well as the terms of payment for the delivery of seeds (cashless or noncash), as well as the cost of the equipment for the seed and cereal production, as well as the cost of the seed cereals, reflects and affects the relationship.

-organizational and demographic factors - the forms of economic management and competition, the form of sales and demand, the dislocations and the origin of the population, the population, population and density, demographic situation, etc. The case is more explicitly stated by the presence of various administrative interventions and lack of competitors in the region, and the ability to formulate the proposal by identifying the actual status of the demand for seeds and the dislocation of the demographic situation.

-natural and geographical factors - natural and climatic conditions of the territory of the seeding camp, the effect of climatic conditions - i.e., the annual solar days and the effective temperature, geographical location - distance to infrastructure objects, the condition of facilities and transport facilities, etc.

With a broader description of the Factorial group, the natural climatic conditions and effects of the region will be affected by the storage and cultivation of coconut seeds.

Depending on the geographical location, it is the ability to take account of the implementation of various organizational and economic practices. In particular, the Ferghana Valley and the Republic of Karakalpakstan are regions with a natural contrast with each other. 
Factors influencing the relationship between organizations of coconut seeds *

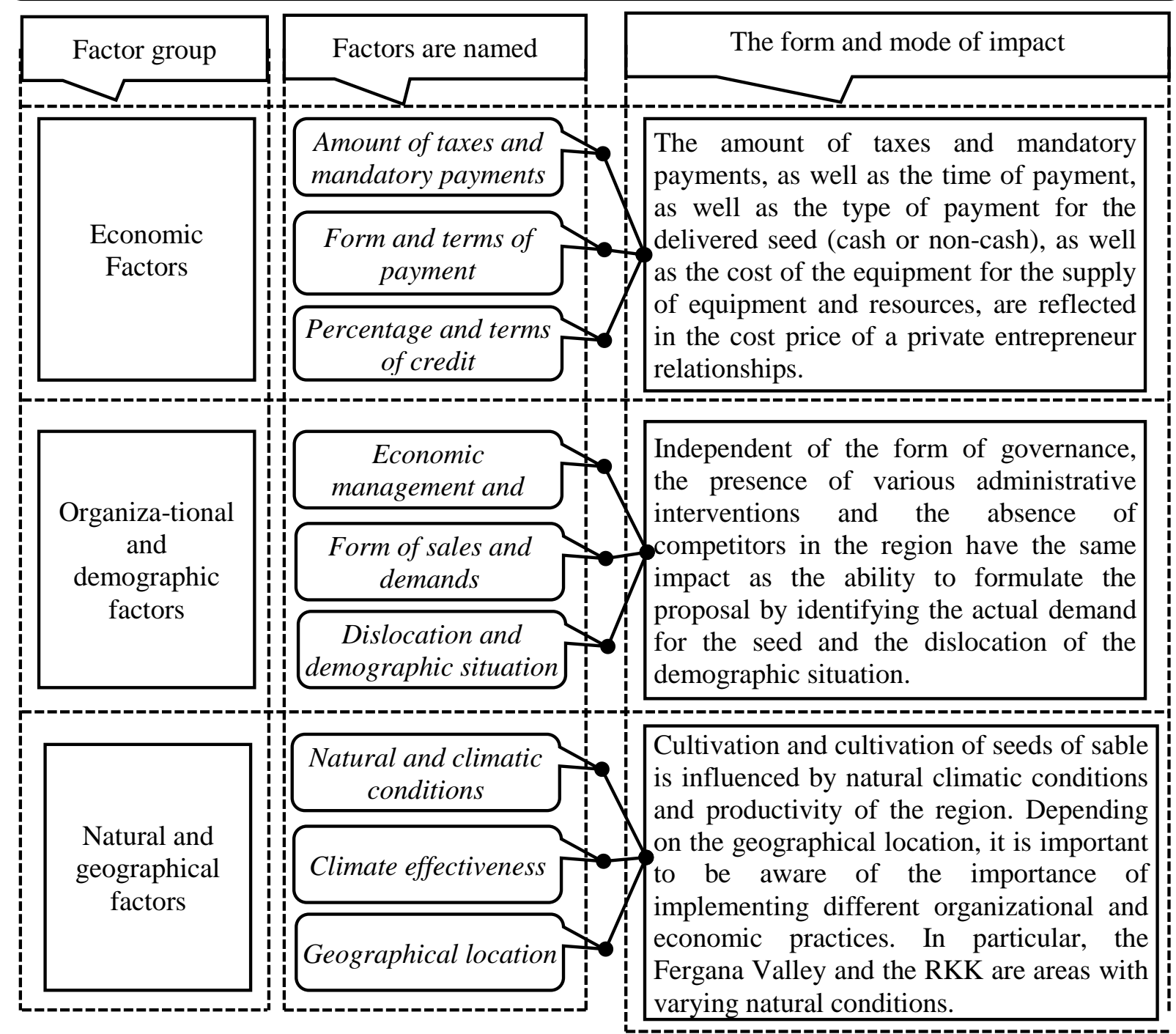

* Note: The monographs conducted by the researchers have been selected in a relatively high proportion

Figure. Factors influencing the relationship between organizations of coconut seeds.

\section{References:}

1. Razzoqov, A., Toshmatov, Sh., \& Ormonov, N. (2002). Iqtisodiy ta'limotlar tarixi "Darslik". Tashkent: Moliya. 145 b. (in Uzbek).

2. Madyarov, R., \& Umarov, R. (2013). State of the Art and Prospects of Development Sericulture in Uzbekistan. In: Proceedings of the Scientific and Technical Reports, 6th BACSA International Conference "Building Value Chains in Sericulture”. BISERICA, 2013, 182-195.

3. Asqarov, N., \& Djurayev, B. (2018). Development of effective forms of the entrepreneurship on the silkworm seed system. Bulletin of Science and Practice, 4(11), 263-268.

4. Bakhriddinov, A., (2018). The development of cooperation and integration processes in sericulture subcomplex of an agroindustrial complex of Uzbekistan. Bulletin of Science and Practice, 4(11), 329-336. (in Russian). 


\section{Список литературь:}

1. Razzoqov A., Toshmatov Sh., O`rmonov N. Iqtisodiy ta'limotlar tarixi "Darslik". Tashkent: Moliya, 2002. 145 p. (in Uzbek).

2. Madyarov R., Umarov R. State of the Art and Prospects of Development Sericulture in Uzbekistan // Proceedings of the Scientific and Technical Reports, 6th BACSA International Conference "Building Value Chains in Sericulture". BISERICA, 2013. P. 182-195.

3. Asqarov N., Djurayev B. Development of effective forms of the entrepreneurship on the silkworm seed system // Бюллетень науки и практики. 2018. Т. 4. №11. С. 263-268.

4. Бахриддинов A. Р. Развитие кооперации и интеграционных процессов в шелководческом подкомплексе АПК Узбекистана // Бюллетень науки и практики. 2018. Т. 4. №11. С. 329-336.

Работа поступила в редакиию 09.03.2019 г.
Принята к публикаичии 14.03.2019 2.

Cite as (APA):

Askarov, N., \& Sadullayev, U. The Scientific Basis of the Relationships Between Silk Seed Production Companies in Uzbekistan. Bulletin of Science and Practice, 5(4), 301-306. https://doi.org/10.33619/2414-2948/41/41.

Ссылка для циитирования:

Askarov N., Sadullayev U. The Scientific Basis of the Relationships Between Silk Seed Production Companies in Uzbekistan // Бюллетень науки и практики. 2019. Т. 5. №4. С. 301-306. https://doi.org/10.33619/2414-2948/41/41. 